\title{
Coronavirus Disease Case Definitions, Diagnostic Testing Criteria, and Surveillance in 25 Countries with Highest Reported Case Counts
}

\author{
Amitabh B. Suthar, ${ }^{1}$ Sara Schubert, ${ }^{1}$ Julie Garon, Alexia Couture, Amy M. Brown, Sana Charania
}

We compared case definitions for suspected, probable, and confirmed coronavirus disease (COVID-19), as well as diagnostic testing criteria, used in the 25 countries with the highest reported case counts as of October 1 , 2020. Of the identified countries, $56 \%$ followed World Health Organization (WHO) recommendations for using a combination of clinical and epidemiologic criteria as part of the suspected case definition. A total of $75 \%$ of identified countries followed $\mathrm{WHO}$ recommendations on using clinical, epidemiologic, and diagnostic criteria for probable cases; $72 \%$ followed WHO recommendations to use PCR testing to confirm COVID-19. Finally, $64 \%$ of countries used testing eligibility criteria at least as permissive as WHO. We observed marked heterogeneity in testing eligibility requirements and in how countries define a COVID-19 case. This heterogeneity affects the ability to compare case counts, transmission, and vaccine effectiveness, as well as estimates derived from case surveillance data across countries.

$\mathrm{N}$ Tovel infectious pathogens can pose major challenges to global health and security. Tracking the geography, demographics, and suspected mode of transmission of these pathogens by using a standardized case definition remains the foundation for infectious disease surveillance (1). Severe acute respiratory syndrome coronavirus 2 (SARS$\mathrm{CoV}-2)$, the virus that causes coronavirus disease (COVID-19), was first characterized in December 2019 (2). By January 2020, the first national case definition was developed (3) and the World Health Organization (WHO) declared a public health emergency of international concern (4). WHO's interim

Author affiliation: Centers for Disease Control and Prevention,

Atlanta, Georgia, USA guidance for global COVID-19 surveillance, released on January 31, 2020, provided a hierarchy of confirmed, probable, and suspected case definitions (5). This guidance encouraged the use of all available clinical, epidemiologic, and laboratory evidence for case classification purposes and noted that countries might need to adapt these definitions to their unique epidemiologic situations. Recommendations for testing suspected cases and widespread testing on the basis of transmission intensity, number of cases, and available resources were included.

Both WHO and national case definitions have evolved as knowledge about COVID-19 etiology and the myriad of ways the disease manifests after infection has grown (5-7). Early on, surveillance emphasized a travel history to Wuhan, China, where the initial outbreak occurred, and a narrowly defined set of symptoms. However, the virus rapidly spread to other provinces in China and then internationally, and reports of patients who experienced new symptoms or remained asymptomatic increased (8). Confirming a COVID-19 cas relies on diagnostic testing; therefore, testing capacity has played a vital role in COVID-19 surveillance efforts. The types of tests available have expanded to include molecular and antigen tests to detect the presence of the SARS-CoV-2 virus and serologic tests to detect antibodies produced from previous SARS-CoV-2 infection $(9,10)$. However, the availability of these tests and the resources needed to collect, handle, and process clinical specimens have varied widely across nations (11). Shortages of test kits and reagents and lack of laboratory capacity have forced officials in many locations to make difficult decisions about testing eligibility (12). 
Differences in testing eligibility criteria and case definitions pose a challenge not only to detecting the actual number of cases within countries, but also to understanding the global burden of disease and adequately responding to pandemics. Global guidelines have been developed for testing eligibility criteria and case definitions but are usually reviewed at a national level and are subject to adaptation on the basis of laboratory and health system considerations. Earlier evaluations of global COVID-19 case definitions do not reflect the latest changes to national case definitions and testing eligibility criteria and do not target the full range of countries with the highest number of reported COVID-19 cases (13-15). We analyzed national COVID-19 case definitions from the 25 countries with the largest number of reported COVID-19 cases as of October 1, 2020 (collectively representing $\approx 85 \%$ of the global cases at that time), and the specific criteria used to determine eligibility for diagnostic testing. We also determined the implications of intercountry differences on ongoing efforts to understand global disease burden and control the pandemic.

\section{Methods}

\section{Design}

We identified the 25 countries with the highest number of reported COVID-19 cases from WHO COVID-19 cumulative case counts as of October 1, 2020 (16). We extracted surveillance case definitions and official testing policies from official government Web sites for the respective countries. If definitions were not available on government Web sites, we extracted definitions from personal communication with Centers for Disease Control and Prevention field staff.

To find these data, we searched government Web sites using these keywords: case definition, suspect case, confirmed case, COVID-19, case criteria, surveillance, testing criteria, guidelines, laboratory, reverse transcription PCR (RT-PCR), and asymptomatic. All surveillance definitions and testing criteria were verified current as of January 1, 2021. Several official policies were not available in English. For these documents, we used Google Translate (https://translate.google.com) to identify definitions and testing policies.

\section{Data Management and Analysis}

To compare case definitions across countries, we classified the components of each definition into 3 parts: diagnostic components including a laboratory test or radiographic imagery; clinical signs and symptoms, such as cough, fever, and severe acute respiratory infection; and epidemiologic criteria, including travel to a high-burden region or contact with a confirmed or suspected case. For each country's testing policy, we reviewed which persons were eligible for diagnostic testing. Countries were classified as testing asymptomatic persons without any additional criteria; testing asymptomatic persons with some epidemiologic criteria, such as contact with a confirmed case; or recommending testing exclusively for symptomatic persons. These analyses were based solely on diagnostic testing eligibility criteria and did not consider exceptions, such as testing asymptomatic persons before travel, asymptomatic testing through the private sector, or local-level mass testing. Exceptions to national testing policies varied on a local level and frequently changed, which made data difficult to procure and unreliable. We compared elements of national case definitions and testing criteria against global norms from WHO.

\section{Source Assessment}

To assess sources, we extracted information on their origin (government source or personal communication) and timeliness (date of publication). We compiled the date of publication and presumed implementation of each country's most recent case definition as verified on January 1, 2021 (Appendix Table 1, https:/ / wwwnc. cdc.gov/EID/article/28/1/21-1082-App1.pdf). Publication dates range from March 27, 2020, to December 18,2020 , for case definitions and July 6,2020 , to January 1, 2021, for testing policies.

\section{Results}

\section{Suspected Case Definitions}

We identified suspected case definitions in 24 (96\%) of 25 countries (Table 1; Appendix Tables 2,3). Although Israel does not have an official suspected case definition, persons are considered suspected on the basis of contact with confirmed cases, which is determined by digital surveillance of cellphones. We interpreted Israel's suspected contact determined by cellphones to be an epidemiologic criterion. The 3 most common criteria in suspected case definitions were fever (reported in 92\% of countries), cough (reported in $84 \%$ of countries), and labored breathing (reported in $84 \%$ of countries). In 7 countries ( $28 \%$ ), other criteria were used in addition to common criteria (Table 1). The WHO suspected case definition relies on clinical symptoms, including the 3 most common, and epidemiologic criteria. A total of 14 (56\%) countries followed this guidance broadly by using clinical and 
Table 1. Selected suspected case definition criteria across 25 countries with the highest COVID-19 case counts, current as of January $1,2021^{*}$

\begin{tabular}{|c|c|c|c|c|c|c|c|c|c|c|}
\hline \multirow[b]{2}{*}{ Country } & \multirow[b]{2}{*}{$\begin{array}{c}\text { Diagnostic } \\
\text { testing/laboratory } \\
\text { evidence } \dagger\end{array}$} & \multicolumn{8}{|c|}{ Clinical symptoms } & \multirow[b]{2}{*}{$\begin{array}{c}\text { Epidemiologic } \\
\text { criteria, any }\end{array}$} \\
\hline & & Cough & Fever & SARI & $\begin{array}{l}\text { Labored } \\
\text { breathing }\end{array}$ & Headache & $\begin{array}{c}\text { Muscle } \\
\text { pain }\end{array}$ & $\begin{array}{l}\text { Loss of } \\
\text { taste or } \\
\text { smell }\end{array}$ & Diarrhea & \\
\hline $\begin{array}{l}\text { WHO definition } \\
\text { (reference) }\end{array}$ & & $x$ & $\mathrm{X}$ & $X$ & $\mathrm{X}$ & $\mathrm{X}$ & $\mathrm{X}$ & & $\mathrm{X}$ & $\mathrm{X}$ \\
\hline Argentina & & $x$ & $X$ & $X$ & $x$ & $x$ & $x$ & $X$ & $x$ & $x$ \\
\hline Bangladesh $\ddagger$ & & $X$ & $X$ & $x$ & $X$ & $x$ & $X$ & & $X$ & $X$ \\
\hline Brazil & & $X$ & $X$ & $x$ & $x$ & $X$ & & $X$ & $X$ & \\
\hline Chile & & $X$ & $X$ & $\mathrm{X}$ & $\mathrm{X}$ & $X$ & $x$ & $X$ & $X$ & $X$ \\
\hline Colombia & $X$ & $x$ & $x$ & & $X$ & $x$ & $x$ & $x$ & $X$ & $X$ \\
\hline France§ा & & $X$ & $x$ & & $x$ & $X$ & $X$ & $X$ & $X$ & \\
\hline Germany§ণ & & $X$ & $x$ & & $x$ & $X$ & $X$ & $X$ & $X$ & \\
\hline India\# & & $X$ & $x$ & $x$ & $x$ & & & & & $x$ \\
\hline Indonesia & & & $x$ & $x$ & $x$ & & & & & $X$ \\
\hline Iran & & & $x$ & $x$ & & & & & & $X$ \\
\hline Iraq & & $X$ & $x$ & $x$ & $x$ & $x$ & $x$ & & $X$ & $X$ \\
\hline Israel $^{* *}$ & & & & & & & & & & $X$ \\
\hline Italy§ণ & & $X$ & $x$ & & $x$ & $x$ & $x$ & $x$ & $X$ & \\
\hline Mexico & & $X$ & $X$ & & $x$ & $x$ & $x$ & $X$ & & \\
\hline Pakistan\# & & $X$ & $X$ & $X$ & $x$ & & & & & $x$ \\
\hline Peru & & $X$ & $X$ & $x$ & $x$ & $X$ & & & & \\
\hline Philippinesł & & $X$ & $X$ & $x$ & $x$ & $X$ & $X$ & & $X$ & $X$ \\
\hline Russia & & $X$ & $X$ & & $x$ & & $x$ & $X$ & $X$ & \\
\hline Saudi Arabia & & $X$ & $X$ & $X$ & $x$ & $X$ & & $X$ & $X$ & $X$ \\
\hline South Africa & & $X$ & $X$ & $x$ & $x$ & & $X$ & $X$ & $X$ & $x$ \\
\hline Spain & & $X$ & $x$ & $x$ & $x$ & $x$ & $x$ & $X$ & $X$ & \\
\hline Turkey & & $x$ & $x$ & $x$ & $x$ & $x$ & $x$ & $x$ & $x$ & $X$ \\
\hline Ukraine & & $X$ & $X$ & $x$ & $x$ & & & & & $x$ \\
\hline United Kingdom & & $x$ & $x$ & & & & & $X$ & & \\
\hline United States & $X$ & & & & & & & & & \\
\hline $\begin{array}{l}\text { No. }(\%) \text { countries } \\
\text { including } \\
\text { criterion†† }\end{array}$ & $2(8)$ & $21(84)$ & $\begin{array}{l}23 \\
(92)\end{array}$ & $\begin{array}{c}16 \\
(64)\end{array}$ & $21(84)$ & $15(60)$ & $14(56)$ & $14(56)$ & $15(60)$ & $16(64)$ \\
\hline \multicolumn{11}{|c|}{$\begin{array}{l}\text { *Complete data are available in Appendix Table } 3 \text { (https://wwwnc.cdc.gov/EID/article/28/1/21-1082-App1.pdf). X indicates the criterion was sufficient for, } \\
\text { or a potential component of, the suspected case definition requirement(s). COVID-19, coronavirus disease; SARI, severe acute respiratory infection; } \\
\text { WHO, World Health Organization. } \\
\text { tSee suspected case definition for applicable country (Appendix Table 2). } \\
\text { †World Health Organization definition (updated August 2020). } \\
\text { §European Centre for Disease Prevention and Control definition. } \\
\text { १These countries consider these definitions as possible not suspected cases; because of the comparability between possible and suspected, we treated } \\
\text { these definitions as a suspected definition. } \\
\text { \#World Health Organization definition (updated March 2020). } \\
\text { **Israel does not have an official suspect case definition; persons are considered suspected on the basis of contact with confirmed cases determined by } \\
\text { digital surveillance of cellphones. } \\
\text { t†Denominator is } 24 \text { countries with suspected case definition. }\end{array}$} \\
\hline
\end{tabular}

epidemiologic criteria, $10(40 \%)$ countries required clinical symptoms alone for the suspected case definition, and 2 countries (8\%) also incorporated diagnostic testing. The United States relies on laboratory evidence, including antibody or antigen positivity, without any clinical symptoms or epidemiologic criteria, whereas Colombia primarily relies on epidemiologic criteria and clinical symptoms but includes laboratory and radiologic tests as part of their definition to assist with diagnoses $(17,18)$.

\section{Probable Case Definitions}

We identified probable case definitions in 16 (64\%) of 25 countries (Table 2; Appendix Tables 4,5). The remaining $9(36 \%)$ countries chose not to use a probable case definition and instead use only suspected and confirmed case definitions. The WHO probable case definition includes criteria from all 3 categories: diagnostic testing (chest imaging), clinical symptoms, and epidemiologic criteria. Of the 16 countries, $12(75 \%)$ were consistent with WHO and included criteria from all 3 categories. The number of required criteria across countries was heterogeneous. The 3 most common criteria in probable case definitions were fever (reported in $94 \%$ of 16 countries), labored breathing (reported in $88 \%$ of 16 countries), and confirmed contact with a probable or confirmed case (reported in $81 \%$ of 16 countries). Fourteen $(88 \%)$ countries included diagnostic testing for the probable case definition, 15 (94\%) included clinical symptoms in their definitions, and 14 (88\%) included epidemiologic criteria. 


\section{Confirmed Case Definitions}

We identified confirmed case definitions in all 25 countries (100\%) (Table 3; Appendix Tables 6,7). All confirmed case definitions required diagnostic testing. A total of 18 (72\%) countries were consistent with WHO's recommendations and specified RT-PCR tests in their case definition. Of these countries, 10 (40\%) also included antigen or antibody tests in their definition. In 7 (28\%) countries, the type of diagnostic test was not specified. Reference to the suspected case definition within the confirmed case definition was included in 7 (28\%) of countries. Of these, Mexico, Saudi Arabia, and Turkey required that a person meet the suspected case definition in addition to diagnostic testing criteria. In addition to confirming cases on the basis of diagnostic testing, 6 (24\%) countries confirmed cases exclusively on the basis of loss of taste or smell (anosmia or ageusia). Overall, 8 countries (32\%) included clinical symptoms as part of their confirmed case definition.

\section{Testing Eligibility Criteria}

We identified testing criteria in all 25 countries (100\%) (Appendix Table 8). Of those, 8 (32\%) countries had no symptom requirements for testing, 8 (32\%) had no symptom requirements for testing but required epidemiologic criteria (i.e., exposure to a confirmed or probable case), and 9 (36\%) countries required symptoms. Of the 8 countries requiring epidemiologic criteria, $5(63 \%)$ also allowed testing for asymptomatic healthcare workers (Appendix Table 8). Policies from Saudi Arabia and the United Kingdom specified not to test asymptomatic persons but included an exception for healthcare workers (Appendix Table 8). WHO recommends testing asymptomatic persons who have had contact with a confirmed case; $64 \%$ of countries used eligibility criteria at least as permissive as WHO.

\section{Source Assessment}

We found $92 \%$ of case definitions on government Web sites, and $72 \%$ were published or included in

\begin{tabular}{|c|c|c|c|c|c|c|c|c|c|c|c|}
\hline \multirow[b]{2}{*}{ Country } & \multicolumn{3}{|c|}{ Diagnostic testing } & \multicolumn{5}{|c|}{ Clinical symptoms } & \multicolumn{3}{|c|}{ Epidemiologic criteria } \\
\hline & $\begin{array}{c}\text { Inconcl. } \\
\text { test }\end{array}$ & $\begin{array}{c}\text { Antigen } \\
\text { test }\end{array}$ & $\begin{array}{l}\text { Radiograph } \\
\text { imaging }\end{array}$ & Cough & Fever & SARI & $\begin{array}{l}\text { Labored } \\
\text { breathing }\end{array}$ & $\begin{array}{l}\text { Loss of } \\
\text { taste or } \\
\text { smell }\end{array}$ & $\begin{array}{l}\text { Travel } \\
\text { history }\end{array}$ & Hosp. & $\begin{array}{c}\text { Confirmed } \\
\text { contact }\end{array}$ \\
\hline $\begin{array}{l}\text { WHO definition } \\
\text { (reference) } \\
\text { Argentina }\end{array}$ & & & $x$ & $\mathrm{X}$ & $\mathrm{X}$ & $\mathrm{X}$ & $\mathrm{X}$ & $\mathrm{X}$ & $\mathrm{X}$ & $X$ & $\mathrm{X}$ \\
\hline $\begin{array}{l}\text { Bangladesh } \uparrow \\
\text { Brazil }\end{array}$ & & & $\mathrm{X}$ & $\mathrm{X}$ & $X$ & $X$ & $X$ & $X$ & $\mathrm{X}$ & $X$ & $\mathrm{X}$ \\
\hline Chile & $X$ & $X$ & $X$ & $x$ & $x$ & $x$ & $X$ & $x$ & & $x$ & $x$ \\
\hline Colombia & $X$ & & & $X$ & $X$ & & $x$ & $x$ & $X$ & & $x$ \\
\hline France‡ & & & $X$ & $X$ & $x$ & & $X$ & $\mathrm{X}$ & & & $x$ \\
\hline Germanył & & & $X$ & $X$ & $x$ & & $X$ & $\mathrm{x}$ & & & $\mathrm{X}$ \\
\hline $\begin{array}{l}\text { India§ } \\
\text { Indonesia }\end{array}$ & $X$ & & & $X$ & $\begin{array}{l}X \\
X\end{array}$ & $\begin{array}{l}X \\
X\end{array}$ & $\begin{array}{l}X \\
X\end{array}$ & & $X$ & $X$ & $X$ \\
\hline Iran & & & $X$ & & $x$ & $x$ & & $x$ & $\mathrm{X}$ & & $X$ \\
\hline $\begin{array}{l}\text { Iraq† } \\
\text { Israel }\end{array}$ & & & $X$ & $X$ & $X$ & $X$ & $X$ & $\mathrm{X}$ & $X$ & $X$ & $X$ \\
\hline $\begin{array}{l}\text { Italy } \neq \\
\text { Mexico }\end{array}$ & & & $\mathrm{X}$ & $\mathrm{X}$ & $X$ & & $X$ & $\mathrm{X}$ & & & $X$ \\
\hline $\begin{array}{l}\text { Pakistan§ } \\
\text { Peru }\end{array}$ & $X$ & & & $\mathrm{X}$ & $X$ & $x$ & $x$ & & $\mathrm{X}$ & $X$ & $X$ \\
\hline Philippines† & & & $X$ & $X$ & $X$ & $\mathrm{X}$ & $\mathrm{X}$ & $x$ & $\mathrm{X}$ & $X$ & $\mathrm{X}$ \\
\hline $\begin{array}{l}\text { Russia } \\
\text { Saudi Arabia }\end{array}$ & & & & $\mathrm{X}$ & $X$ & $X$ & $\mathrm{X}$ & $\mathrm{X}$ & $\mathrm{X}$ & & $X$ \\
\hline South Africa & & & & & & & & & & & \\
\hline $\begin{array}{l}\text { Spain } \\
\text { Turkey }\end{array}$ & $X$ & & $\mathrm{X}$ & $X$ & $X$ & $X$ & $\mathrm{X}$ & $\mathrm{X}$ & & & \\
\hline $\begin{array}{l}\text { Ukraine } \\
\text { United Kingdom }\end{array}$ & $X$ & & & & & & & & & & \\
\hline United States & & $X$ & $X$ & $X$ & $X$ & $X$ & $X$ & $X$ & & & $X$ \\
\hline $\begin{array}{l}\text { No. }(\%) \text { countries } \\
\text { including criterion }\end{array}$ & $6(38)$ & $2(13)$ & $10(63)$ & $13(81)$ & $\begin{array}{r}15 \\
(94) \\
\end{array}$ & $\begin{array}{c}11 \\
(69) \\
\end{array}$ & $14(88)$ & $12(75)$ & $8(50)$ & $6(38)$ & $13(81)$ \\
\hline $\begin{array}{l}\text { *Complete data are ave } \\
\text { Appendix Table } 4 . \mathrm{X} \text { in } \\
\text { coronavirus disease; } \\
\text { †World Health Organiz } \\
\text { †European Centre for } \\
\text { \$World Health Organiz } \\
\text { TDenominator is } 16 \text { col }\end{array}$ & $\begin{array}{l}\text { lable in Ap } \\
\text { icates the c } \\
\text { sp., hospita } \\
\text { tion definiti } \\
\text { isease Pre } \\
\text { tion definiti }\end{array}$ & $\begin{array}{l}\text { endix Tabl } \\
\text { iterion was } \\
\text { ized; incon } \\
\text { n (updated } \\
\text { ention and } \\
\text { n (updated }\end{array}$ & $\begin{array}{l}5 \text { (https://www } \\
\text { sufficient for, o } \\
\text { l., inconclusive } \\
\text { August 2020). } \\
\text { Control definitio } \\
\text { March 2020). }\end{array}$ & $\begin{array}{l}\text { dc.gov/E } \\
\text { otential c } \\
\text { RI, sever }\end{array}$ & $\begin{array}{l}\text { D/article/ } \\
\text { omponen } \\
\text { e acute re }\end{array}$ & $\begin{array}{l}28 / 1 / 21 \\
\text { t of, the } \\
\text { espirator }\end{array}$ & $\begin{array}{l}\text { 1082-App1. } \\
\text { probable ca } \\
\text { infection; }\end{array}$ & $\begin{array}{l}\text { f); full pro } \\
\text { definition } \\
-10 \text {, World }\end{array}$ & $\begin{array}{l}\text { e case de } \\
\text { uirement( } \\
\text { alth Orga }\end{array}$ & $\begin{array}{l}\text { finitions } \\
\text { f. COVIL } \\
\text { ization. }\end{array}$ & $\begin{array}{l}\text { re shown in } \\
-19 \text {, }\end{array}$ \\
\hline
\end{tabular}


Table 3. Selected confirmed case definition criteria across 25 countries with the highest COVID-19 case counts, current as of January $1,2021^{*}$

\begin{tabular}{|c|c|c|c|c|c|c|c|c|c|c|}
\hline \multirow[b]{2}{*}{ Country } & \multicolumn{5}{|c|}{ Diagnostic testing } & \multicolumn{2}{|c|}{ Clinical symptoms } & \multicolumn{3}{|c|}{ Epidemiologic criteria } \\
\hline & $\begin{array}{l}\text { PCR } \\
\text { test }\end{array}$ & $\begin{array}{c}\text { Antigen } \\
\text { test }\end{array}$ & $\begin{array}{l}\mathrm{Ab} \\
\text { test }\end{array}$ & $\begin{array}{l}\text { Positive } \\
\text { test (NS) }\end{array}$ & $\begin{array}{l}\text { Radiograph } \\
\text { imaging }\end{array}$ & $\begin{array}{c}\text { Meet } \\
\text { suspected } \\
\text { case definition }\end{array}$ & $\begin{array}{l}\text { Loss of } \\
\text { taste or } \\
\text { smell }\end{array}$ & $\begin{array}{l}\text { Travel } \\
\text { history }\end{array}$ & Hosp. & $\begin{array}{c}\text { Confirmed } \\
\text { contact }\end{array}$ \\
\hline $\begin{array}{l}\text { WHO definition } \\
\text { (reference) }\end{array}$ & $X$ & & & & & & & & & \\
\hline Argentina & $X$ & $x$ & & & & $x$ & $x$ & & & $X$ \\
\hline Bangladesh† & $X$ & & & & & & & & & \\
\hline Brazil & $x$ & $x$ & $x$ & & $X$ & & $X$ & & & $X$ \\
\hline Chile & $x$ & & & & & $\mathrm{X}$ & $X$ & & $X$ & \\
\hline Colombia & $X$ & $X$ & & & & & & & & \\
\hline France & $X$ & $\mathrm{X}$ & & & & & & & & \\
\hline Germanył & $X$ & $x$ & & & & & & & & \\
\hline India† & & & & $X$ & & & & & & \\
\hline Indonesia & $X$ & & & & & & & & & \\
\hline Iran & & & & $\mathrm{X}$ & & & & & & \\
\hline Iraq† & $\mathrm{X}$ & & & & & & & & & \\
\hline Israel & & & & $\mathrm{X}$ & & & & & & \\
\hline Italył & $X$ & $X$ & & & & & & & & \\
\hline Mexico & & & & $X$ & & $\mathrm{X}$ & $\mathrm{X}$ & & & $\mathrm{X}$ \\
\hline Pakistan † & & & & $X$ & & & & & & \\
\hline Peru & $\mathrm{X}$ & $x$ & & & & $\mathrm{X}$ & & $\mathrm{X}$ & $X$ & $\mathrm{X}$ \\
\hline Philippines $†$ & $X$ & $x$ & & & & & & & & \\
\hline Russia & $\mathrm{X}$ & $\mathrm{X}$ & $\mathrm{X}$ & & & & & & & \\
\hline Saudi Arabia & $X$ & & & & & $x$ & & $X$ & $x$ & $x$ \\
\hline South Africa & $\mathrm{X}$ & & & & & & & & & \\
\hline Spain & $\mathrm{X}$ & $x$ & & & & $X$ & $X$ & & & \\
\hline Turkey & $X$ & & & & & $x$ & $x$ & $\mathrm{X}$ & $\mathrm{X}$ & $X$ \\
\hline Ukraine & & & & $\mathrm{X}$ & & & & & & \\
\hline United Kingdom & & & & $\mathrm{X}$ & & & & & & \\
\hline United States & X & & & & & & & & & \\
\hline No. $(\%)$ countries§ & $18(72)$ & $10(40)$ & $2(8)$ & $7(28)$ & $1(4)$ & $7(28)$ & $6(24)$ & $3(12)$ & $4(16)$ & $6(24)$ \\
\hline $\begin{array}{l}{ }^{*} \text { Complete data are av } \\
\text { or a potential compone } \\
\text { hosp., hospitalized; NS } \\
\text { †World Health Organiz } \\
\text { †European Centre for } \\
\text { §Denominator is } 25 \mathrm{co}\end{array}$ & $\begin{array}{l}\text { lable in App } \\
\text { t of, the cor } \\
\text { not specifie } \\
\text { tion definiti } \\
\text { sease Pre } \\
\text { tries with }\end{array}$ & $\begin{array}{l}\text { endix Tabl } \\
\text { firmed case } \\
\text { d; WHO, W } \\
\text { n (confirme } \\
\text { ention and } \\
\text { onfirmed ce }\end{array}$ & $\begin{array}{l}7 \text { (https } \\
\text { definitic } \\
\text { rld Hea } \\
\text { d case } \\
\text { Control }\end{array}$ & $\begin{array}{l}: / / \text { wwwnc.cdc } \\
\text { n requiremer } \\
\text { Ith Organizati } \\
\text { efinition did } n \\
\text { lefinition. } \\
\text { tions. }\end{array}$ & $\begin{array}{l}\text { gov/EID/article/ } \\
\text { t(s). Full confirn } \\
\text { on. } \\
\text { ot change betw }\end{array}$ & $\begin{array}{l}\text { 1/21-1082-App1.p } \\
\text { case definitions ce } \\
\text { March } 2020 \text { and }\end{array}$ & $\begin{array}{l}\text { if); } X \text { indica } \\
\text { in be found } \\
\text { ugust } 2020\end{array}$ & $\begin{array}{l}\text { the criter } \\
\text { Appendix } \\
\text { date). }\end{array}$ & $\begin{array}{l}\text { Ion was s } \\
\text { Table } 6 .\end{array}$ & $\begin{array}{l}\text { ufficient for, } \\
\text { Ab, antibody; }\end{array}$ \\
\hline
\end{tabular}

documents published after the most recent $\mathrm{WHO}$ definition was published (August 7, 2020) (Appendix Table 1). India and Pakistan used the previous WHO definition (dated March 2020); we could not confirm that these countries updated their definition on the basis of the newest WHO definitions. We could not locate definitions on government Web sites for Israel, Iraq, and Iran; for these countries, we obtained definitions from personnel involved in the country's COVID-19 response. Of 25 countries, 23 (92\%) had an official government source for diagnostic testing criteria. In total, $88 \%$ of testing criteria were published after September 1, 2020. The policies for Philippines, Brazil, and Pakistan were updated in July and August 2020.

\section{Discussion}

All iterations of WHO's global COVID-19 surveillance guidance state that countries might need to adapt case definitions to their specific circumstances $(5-7,19)$. Beginning with the March 20, 2020, version,
WHO also encouraged countries to publish their adapted versions online and in periodic situation reports $(6,7)$. Nearly all countries $(92 \%)$ in this analysis chose to deviate from WHO case definitions; $92 \%$ of countries posted their case definition on a government Web site. Suspected and confirmed case classifications were found for nearly all countries, but $36 \%$ excluded the probable case classification. In addition, we observed substantial variation among testing criteria used in national case definitions. Although WHO reserved the use of laboratory testing for confirmed cases only, $2(8 \%)$ countries included laboratory evidence for suspected cases and 14 (88\%) for probable cases; $32 \%$ included nonlaboratory criteria for confirmed cases. Laboratory evidence in some countries was not restricted to RT-PCR and included increasingly available antigen and antibody tests. Testing eligibility criteria also differed widely; many countries either excluded asymptomatic persons from routine testing (36\%) or only included them under certain conditions (32\%). 
Differences in case definitions and testing eligibility can affect efforts to monitor disease trends and determine the impact and effectiveness of vaccines across countries and over different periods. As knowledge of a novel disease increases, the sensitivity and specificity of the case definition changes over time, ultimately affecting the number of cases identified (20). For example, during the 2002-2003 severe acute respiratory syndrome outbreak, several iterations of case definitions in the Netherlands diverged from the more sensitive and less specific WHO case definition. When all cases were reevaluated, 21 cases were classified as suspected and 2 as probable according to the latest WHO case definition, as opposed to 9 suspected and zero probable cases according to the Netherlands case definitions (21). As the COVID-19 pandemic emerged in China, a February 12,2020 , change to the case definition to include clinically diagnosed mild cases resulted in identification of $>15,000$ cases (22). A study of successive case definitions in China, each with gradually increasing sensitivity, also yielded higher detection of cases (15). During January 15-March 3, 2020, the National Health Commission of China used 7 versions of the case definition for COVID-19; the study estimates that the proportion of cases detected increased by 7 times after the first change, 3 times from change 2 to 4 , and 4 times after change 5 . The authors estimated that if the fifth version of the case definition had been applied throughout the outbreak, 4.2 times more confirmed cases would have been identified in China by February 20, 2020 (232,000 vs. 55,508). A more recent study benefitting from the availability of the complete genome sequence for SARS-CoV-2 and access to respiratory specimens collected early for retrospective analysis perhaps best demonstrates the effect of a restrictive case definition (23). Those authors identified multiple early cases of SARS-CoV-2 infection in Nottingham, UK, that, despite demonstrating symptoms consistent with COVID-19, did not meet case definition criteria used for diagnostic testing referral in place at the time because of lack of travel history or contact with an infected person. Genomic sequencing of these undetected cases revealed that most were acquired locally by community spread before widespread mitigation measures were adopted. These findings suggest that countries that used less sensitive case definitions, particularly at the start of the pandemic, might have grossly underestimated the true burden of disease, which affected decisions about the need for and timing of infection control measures. Changes in case definitions, both across and within countries, might also need to be considered when analyzing an epidemic curve for COVID-19 or other novel diseases.

The wide variation we found in suspected and probable case criteria and the complete omission of the probable case classification in some nations is of particular interest. WHO indicated that suspected and probable case definitions were revised to reflect increased knowledge of the clinical spectrum of COVID-19 signs and symptoms, especially the most common and predictive. These updates informed global and national surveillance because some symptoms have limited predictive value for surveillance purposes despite their frequent inclusion in case identification procedures (24-27). In its August 7, 2020, guidance, WHO delineated recommendations for handling each case classification. These recommendations included investigating suspected and probable cases for the presence of SARS-CoV-2 by using available laboratory tests, conducting contact tracing with persons with eligible exposure to probable and confirmed cases, and providing specific types of notifications within 24 hours of identifying probable and confirmed cases (8). This guidance also included a new request for countries to include counts of probable cases and confirmed cases in weekly aggregate reports.

WHO case definition guidance does not explicitly state a type of test for diagnostic confirmatory testing but references laboratory guidance that recommend nucleic acid amplification tests (NAATs), such as RT-PCR (28). Many countries might not have considered the laboratory guidance and used the WHO confirmed case definition verbatim. Indeed, we found that 7 countries did not specify a type of test for confirmatory testing. Results indicating some countries' use of alternatives to NAAT as laboratory evidence is another key finding. Antigen tests, particularly pointof-care tests, have been promoted as a tool for early detection and preventing asymptomatic spread (10). However, their sensitivity is generally lower than NAATs, leading to false negatives (29). Antibody tests have typically been recommended as a surveillance assay rather than a standalone diagnostic tool $(12,30)$. Despite the limitations of NAAT alternatives, their increasing availability in many areas and benefits such as lower overall cost, simplified logistics and supply chain management, and faster turnaround of results for rapid versions could explain their integration in some confirmed case definitions.

In all 25 countries, confirmed cases relied on diagnostic testing. Characterizing differences in eligibility for diagnostic testing across countries helps determine whether different persons are being diagnosed 
and designated as a confirmed case. For example, a country that requires symptoms and epidemiologic transmission to be eligible for diagnostic testing might have fewer cases detected than if they permitted testing to all persons in a country regardless of clinical or epidemiologic criteria. Early testing strategies targeted segments of the population believed to be at greatest risk for exposure to SARS-CoV-2. For example, national testing policy in Australia emphasized defining and targeting high-risk settings, such as residential care facilities or correctional facilities (31). In May 2020, the European Centre for Disease Prevention and Control expanded the pool of persons eligible for laboratory testing, resources permitting, to include asymptomatic persons in healthcare settings and long-term care facilities to identify potential sources of infection and protect vulnerable persons (14). WHO recommendations for laboratory testing also evolved over time and acknowledged that testing priorities would depend on intensity of transmission, number of cases, and laboratory capacity. On June 25, 2021, WHO released updated guidance that called on member states to create a national testing strategy that adapts to these changes and to implement public health actions that break transmission chains (32). Specific strategies for different SARS-CoV-2 transmission scenarios might include testing more persons than those who meet the latest suspected and probable case definitions, such as patients with unexpected clinical manifestations, asymptomatic contacts, and samples from existing sentinel surveillance sites. In addition, the guidance includes alternative testing strategies when laboratory capacity is low or overstretched.

Because of the large proportion of asymptomatic or mildly symptomatic COVID-19 cases, detecting both symptomatic and asymptomatic cases is necessary to ensure accurate case counts (33). Including asymptomatic cases also affects key epidemiologic metrics, such as incidence and case-fatality ratio. Although expansive testing criteria would increase the likelihood of detecting asymptomatic infections, this benefit should be weighed against the effect tracing and testing these eligible persons would have on the public health system (31). For example, broadening testing eligibility criteria might overload the healthcare system with persons who have low probability of infection or disease progression. Furthermore, many settings might not have adequate resources to test all eligible persons (33). Although WHO provides harmonious global testing criteria and case definitions, our findings suggest heterogeneity in how these aspects were adapted; it might be necessary to account for these deviations when comparing and collating COVID-19 case counts across countries.

The first limitation of our study is that, although the included studies represented $\approx 85 \%$ of reported cases globally, case definitions in the countries making up the remaining $15 \%$ of cases might differ. In addition, we chose to include the 25 countries with the highest number of reported cases, which might not represent the countries with the highest number of infections. Including countries on the basis of new infections from population-based serosurveillance or other sources merits future research. Second, although we identified suspected case definitions, confirmed case definitions, and testing criteria for most countries, we identified probable case definitions in only 16. This difference could be because of the lack of a probable case definition or its lack of availability in the public domain; regardless, the results of the probable case definition analyses might be less generalizable than the others. Third, we used Google Translate to translate definitions not in English in lieu of direct translation by native or bilingual speakers. Previous studies have used Google Translate for health-related text, including an analysis of national health agency mask guidance across multiple countries and regions during the COVID-19 pandemic (34). One study specifically compared the agreement between translations of abstracted data from published clinical trials between native speakers and Google Translate for 9 different languages and determined that agreement ranged from $85 \%$ to $97 \%$ (35). In our study, translation errors could have occurred for some languages and thus created discrepancies between the original policy intent and our interpretation of the translation. Fourth, our scope was limited to confirmed, probable, and suspected case definitions; other classifications, such as persons under investigation, might merit further research. Fifth, after extraction and analyses were completed, additional issues relating to case surveillance have emerged. These issues include cases amongst vaccinated persons, criteria for distinguishing a new case from an existing case (i.e., reinfection cases), as well as variants (17,36-39). Although these issues were not part of national case surveillance definitions, case surveillance amongst vaccinated persons can help inform stakeholders of changes in vaccine effectiveness, reinfection surveillance might provide further information on naturally acquired and vaccine-acquired immunity, whereas genomic surveillance could provide further insights on circulating strains. All three elements are vital to comprehensive national surveillance of COVID-19. Sixth, given the large number of possibilities, we chose not 
to list every permutation of laboratory, clinical, and epidemiologic criteria for $\mathrm{WHO}$ and national suspected, probable, and confirmed case definitions. Finally, despite our analysis of each government's policies, these policies might not be implemented equally in various settings and could change over time. To continue to build on the implications of this study, further research should determine the programmatic implications of less sensitive case definitions, such as whether misclassifying cases leads to outbreaks and onward population transmission.

Case surveillance remains the foundation for national COVID-19 surveillance and plays a vital role in ongoing situational awareness, clarifying the impact and effectiveness of vaccines and informing other public health and social measures. We observed marked heterogeneity in testing eligibility requirements among countries and how countries define COVID-19 cases. Specifically, we observed heterogeneity in eligible clinical symptoms for suspected case definitions, laboratory and diagnostic requirements for probable case definitions, and eligible laboratory assays for confirmed case definitions. Testing eligibility criteria varied from being restricted to populations with exposure and symptoms to all populations being eligible, regardless of exposure and symptoms. Collectively, these issues suggest that efforts to compare and collate COVID-19 case counts across countries require careful interpretation. Improved harmonization of case definitions across countries prospectively for COVID-19, and for other novel infectious diseases that might emerge, warrants consideration.

This article was preprinted at https:/ / www.medrxiv.org/ content/10.1101/2021.05.11.257047v1.

\section{About the Author}

Dr. Suthar is an epidemiologist in the Center for Global Health, Centers for Disease Control and Prevention. His research interests include infectious disease control, health system design, and digitization within the health sector. Ms. Schubert is a health scientist in the National Center on Birth Defects and Developmental Disabilities, Centers for Disease Control and Prevention. Her research interests include COVID-19 and other infectious disease surveillance and the spatial components of disease.

\section{References}

1. Suthar AB, Allen LG, Cifuentes S, Dye C, Nagata JM. Lessons learnt from implementation of the International Health Regulations: a systematic review. Bull World Health Organ. 2018;96:110-121E. https:/ / doi.org/10.2471/ BLT.16.189100
2. Zhu N, Zhang D, Wang W, Li X, Yang B, Song J, et al.; China Novel Coronavirus Investigating and Research Team. A novel coronavirus from patients with pneumonia in China, 2019. N Engl J Med. 2020;382:727-33. https:/ / doi.org/ 10.1056/NEJMoa2001017

3. National Health Commission of the People's Republic of China. Update on the novel coronavirus pneumonia outbreak [cited 2020 Dec 13]. http:/ / www.nhc.gov.cn/xcs/ yqtb/list_gzbd.shtml

4. World Health Organization. Statement on the second meeting of the International Health Regulations (2005) Emergency Committee regarding the outbreak of novel coronavirus (2019-nCoV) [cited 2020 Dec 13]. https:/ / www. who.int/news/item/30-01-2020-statement-on-the-secondmeeting-of-the-international-health-regulations-(2005)emergency-committee-regarding-the-outbreak-of-novelcoronavirus-(2019-ncov)

5. World Health Organization. Global surveillance for human infection with novel coronavirus (2019-nCoV): interim guidance, 31 January 2020 [cited 2020 Dec 13]. https:/ / apps. who.int/iris/handle/10665/330857

6. World Health Organization. Global surveillance for COVID-19 caused by human infection with COVID-19 virus: interim guidance, 20 March 2020 [cited 2020 Dec 13]. https://apps.who.int/iris/handle/10665/331506

7. World Health Organization. Public health surveillance for COVID-19: interim guidance, 7 August 2020 [cited 2020 Dec 13]. https://apps.who.int/iris/handle/10665/333752

8. Koh D, Cunningham AC. Counting coronavirus disease 2019 (COVID-19) cases: case definitions, screened populations and testing techniques matter. Ann Acad Med Singap. 2020;49:1615. https://doi.org/10.47102/annals-acadmedsg.202038

9. Centers for Disease Control and Prevention. Overview of testing for SARS-CoV-2 (COVID-19) [cited 2021 Jan 29]. https:/ / www.cdc.gov/coronavirus/2019-ncov/hcp/ testing-overview.html

10. Mina MJ, Parker R, Larremore DB. Rethinking Covid-19 test sensitivity - a strategy for containment. N Engl J Med. 2020;383:e120. https:/ / doi.org/10.1056/NEJMp2025631

11. Gilbert M, Pullano G, Pinotti F, Valdano E, Poletto C, Boëlle P-Y, et al. Preparedness and vulnerability of African countries against importations of COVID-19: a modelling study. Lancet. 2020;395:871-7. https:/ / doi.org/10.1016/ S0140-6736(20)30411-6

12. Cheng MP, Papenburg J, Desjardins M, Kanjilal S, Quach C, Libman M, et al. Diagnostic testing for severe acute respiratory syndrome-related coronavirus 2: a narrative review. Ann Intern Med. 2020;172:726-34. https:/ / doi.org/10.7326/M20-1301

13. Atsawarungruangkit A, Yuan J, Kodama T, Cheng MT, Mansouri M, Han B, et al. Evolving global and national criteria for identifying a suspected case of COVID-19. J Int Med Res. 2020;48:300060520938943. https:/ / doi.org/ 10.1177/0300060520938943

14. Peralta-Santos A. Assessment of COVID-19 surveillance case definitions and data reporting in the European Union. July 2020 [cited 2020 Dec 13]. https:/ /www.europarl. europa.eu/RegData/etudes/BRIE/2020/652725/ IPOL_BRI(2020)652725_EN.pdf

15. Tsang TK, Wu P, Lin Y, Lau EHY, Leung GM, Cowling BJ. Effect of changing case definitions for COVID-19 on the epidemic curve and transmission parameters in mainland China: a modelling study. Lancet Public Health. 2020;5: e289-96. https:/ / doi.org/10.1016/S2468-2667(20)30089-X

16. World Health Organization. WHO coronavirus disease (COVID-19) dashboard [cited 2021 Jan 29]. https:/ / covid19.who.int 
17. Centers for Disease Control and Prevention. Coronavirus disease 2019 (COVID-19) 2020 interim case definition, approved August 5, 2020 [cited 2020 Oct 13]. https://ndc.services.cdc.gov/case-definitions/coronavirusdisease-2019-2020-08-05

18. Ministry of Health and Social Protection, Government of Colombia. Optimization of testing, tracking and isolation program for the monitoring and follow-up of COVID-19 cases and contacts in Colombia [in Spanish]. 2020 Oct 19 [cited 2020 Nov 30]. https:/ / www.minsalud.gov.co/ Normatividad_Nuevo/Decreto\%201374\%20de\%202020.pdf

19. World Health Organization. Global surveillance for COVID-19 disease caused by human infection with novel coronavirus (COVID-19): interim guidance, 27 February 2020 [cited 2020 Dec 13]. https://apps.who.int/iris/ handle/10665/331231

20. Teutsch SM. Considerations in planning a surveillance system. In: Lee LM, Teutsch SM, Thacker SB, St. Louis, ME, editors. Principles and practice of public health surveillance, 3rd ed. Oxford: Oxford University Press; 2010. p. 18-30.

21. Timen A, van Doornum GJJ, Schutten M, Conyn-van Spaendonck MA, van der Meer JW, Osterhaus AD, et al. Public health implications of using various case definitions in The Netherlands during the worldwide SARS outbreak. Clin Microbiol Infect. 2006;12:1214-20. https:/ / doi.org/10.1111/ j.1469-0691.2006.01552.x

22. Wu P, Hao X, Lau EHY, Wong JY, Leung KSM, Wu JT, et al. Real-time tentative assessment of the epidemiological characteristics of novel coronavirus infections in Wuhan, China, as at 22 January 2020. Euro Surveill. 2020;25. https:/ / doi.org/10.2807/1560-7917.ES.2020.25.3.2000044

23. Chappell JG, Tsoleridis T, Clark G, Berry L, Holmes N, Moore C, et al.; on behalf of The Cog-Uk Consortium. Retrospective screening of routine respiratory samples revealed undetected community transmission and missed intervention opportunities for SARS-CoV-2 in the United Kingdom. J Gen Virol. 2021;102:001595 https:/ / doi.org/ 10.1099/jgv.0.001595

24. Dawson P, Rabold EM, Laws RL, Conners EE, Gharpure R, Yin S, et al. Loss of taste and smell as distinguishing symptoms of coronavirus disease 2019. Clin Infect Dis. 2021;72:682-5. https://doi.org/10.1093/cid/ciaa799

25. Haehner A, Draf J, Dräger S, de With K, Hummel T. Predictive value of sudden olfactory loss in the diagnosis of COVID-19. ORL J Otorhinolaryngol Relat Spec. 2020;82:17580. https:// doi.org/10.1159/000509143

26. Roland LT, Gurrola JG II, Loftus PA, Cheung SW, Chang JL. Smell and taste symptom-based predictive model for COVID-19 diagnosis. Int Forum Allergy Rhinol. 2020;10:8328. https://doi.org/10.1002/alr.22602

27. Yamamoto-Moreno JA, Pineda-Aguilar C, Ruiz-Pérez S, Gortarez-Quintana GL, Ruiz-Dorado MA. Effectiveness of COVID-19 case definition in identifying SARS-CoV-2 infection in northern Mexico. Popul Med. 2020;2:1-8. https://doi.org/10.18332/popmed/127470

28. World Health Organization. Laboratory testing for 2019 novel coronavirus (2019-nCoV) in suspected human cases. 2020 [cited 2020 Dec 18]. https:/ / www.who.int/ publications/i/item/10665-331501

29. Centers for Disease Control and Prevention. Information for laboratories about coronavirus (COVID-19). 2020 [cited 2020 Dec 18]. https://www.cdc.gov/coronavirus/2019-ncov/ lab/resources/antigen-tests-guidelines.html

30. Krajewski R, Gołębiowska J, Makuch S, Mazur G, Agrawal S. Update on serologic testing in COVID-19. Clin Chim Acta. 2020;510:746-50. https:/ / doi.org/10.1016/ j.cca.2020.09.015

31. McArthur L, Sakthivel D, Ataide R, Chan F, Richards JS, Narh CA. Review of burden, clinical definitions, and management of COVID-19 cases. Am J Trop Med Hyg. 2020;103:625-38. https://doi.org/10.4269/ajtmh.20-0564

32. World Health Organization. Recommendations for national SARS-CoV-2 testing strategies and diagnostic capacities: interim guidance, 25 June 2021 [cited 2021 Aug 29]. https://apps.who.int/iris/handle/10665/342002

33. Hanson KE, Caliendo AM, Arias CA, Englund JA, Lee MJ, Loeb M, et al. Infectious Diseases Society of America guidelines on the diagnosis of COVID-19. Clin Infect Dis. 2020 Jun 16 [Epub ahead of print]. https:/ / doi.org/10.1093/ cid/ciaa760

34. Laestadius L, Wang Y, Ben Taleb Z, Kalan ME, Cho Y, Manganello J. Online national health agency mask guidance for the public in light of COVID-19: content analysis. JMIR Public Health Surveill. 2020;6:e19501. https://doi.org/10.2196/19501

35. Jackson JL, Kuriyama A, Anton A, Choi A, Fournier JP, Geier AK, et al. The accuracy of Google Translate for abstracting data from non-English-language trials for systematic reviews. Ann Intern Med. 2019;171:677-9. https://doi.org/10.7326/M19-0891

36. Pan American Health Organization/World Health Organization. Interim guidelines for detecting cases of reinfection by SARS-CoV-2 [cited 2020 Dec 18]. https://www.paho.org/en/documents/interim-guidelinesdetecting-cases-reinfection-sars-cov-2

37. European Centre for Disease Prevention and Control. Reinfection with SARS-CoV: considerations for public health response, 21 September 2020 [cited 2020 Dec 18]. https:/ / www. ecdc.europa.eu/sites/default/files/documents/Re-infectionand-viral-shedding-threat-assessment-brief.pdf

38. World Health Organization. Guidance for surveillance of SARS-CoV-2 variants [cited 2021 Oct 18]. https:// www.who. int/publications/i/item/WHO_2019-nCoV_surveillance_ variants

39. World Health Organization. Guidance on conducting vaccine effectiveness evaluations in the setting of new SARS-CoV-2 variants [cited 2021 Oct 18]. https:/ / www.who. int/publications/i/item/WHO-2019-nCoV-vaccine_ effectiveness-variants-2021.1

Address for correspondence: Amitabh Bipin Suthar, Centers for Disease Control and Prevention, 1600 Clifton Rd NE, Mailstop US1-2, Atlanta, GA 30329-4027, USA; email: icf4@cdc.gov 